\title{
Results Regarding the Influence of Plum (Prunus Domestica) Fruit Thinning over Production and Fruits Firmness
}

\author{
Flavia Andreea TRIPON ${ }^{1 *}$, Viorel MITRE $^{1)}$ and Monica PAL ${ }^{1)}$ \\ ${ }^{1)}$ Department of Fruit growing. University of Agricultural Sciences and Veterinary Medicine, \\ Cluj-Napoca, Romania. \\ ${ }^{*}$ Corresponding author, e-mail: andreeaflavia_tripon@yahoo.com
}

Bulletin UASVM Horticulture 71(2) / 2014

Print ISSN 1843-5254, Electronic ISSN 1843-5394

DOI:10.15835/buasvmcn-hort:10636

\begin{abstract}
The removal of the excess fruit can be done in three stages: in the bud stage, by cuts, in the blossom stage, by chemical treatements and in the period when the fruit start to grow, through chemical treatements or through hand-thinning. In this study, chemical thinning was applied to flowers when $80 \%$ were open. The study took place in fruit-growing ecosystems Călacea and Steluța, different ecosystems in terms of climate, by analyzing 7 varieties of plum. On these varieties were conducted determinations regarding thinning influence on: flower pollination (\%), fruit weight (g) and fruit firmness $\left(\mathrm{Kgf} / \mathrm{cm}^{2}\right)$. In Călacea fruit-growing ecosystem, regardless the treatment, ,Tuleu Timpuriu' variety registered the highest percentage of binding/ fertilized flowers (28.66\%), and in Agroindustriala fruit-growing ecosystem, the highest percentage was obtained by ,Vinete Românești' variety (29.16\%). Analyzing fruit firmness, in Călacea fruit-growing ecosystem, regardless the treatment, ,Stanley' variety registered the highest fruit firmness (36.95 kgf/ $\mathrm{cm}^{2}$ ), and in Agroindustriala fruit-growing ecosystem, the highest values for fruit firmness were obtained by 'Stanley' (36.55 kgf $\left./ \mathrm{cm}^{2}\right)$. Analyzing fruit weight, in Călacea fruitgrowing ecosystem the highest fruit weight (g) was registered by ,Stanley' variety (48.05g), and in Agroindustriala fruit-growing ecosystem the highest values for fruit weight were obtained by ,Nectarină Roșie' variety (53.41 g).
\end{abstract}

Keywords: concentration, fruit quality, superior quality, thinning flowers, thinning fruits

Introduction. Fruit size depends mostly on the total number of fruits on the tree (Webster, 2000). Giving the fact that plum have a tendency to produce a large number of flowers, and a great number of fruits also, thinning is crucial (Wilkie et al. 2008; Dagar et al. 2012).

Aims and objectives. Present study aims to highlight the results of chemical thinning for two different ecosystems in terms of climate. In Călacea ecosystem, the annual medium temperature in the last 10 years was $11,2^{\circ} \mathrm{C}$ and rainfall quantity in the current year was $562 \mathrm{~mm}$. For Agroindustriala ecosystem the annual medium temperature in the last 10 years was $12,1^{\circ} \mathrm{C}$ and rainfall quantity in the current year was $501.1 \mathrm{~mm}$.

Materials and methods. Experience was conducted from 2013 to 2014. The study took place in fruit-growing ecosystems Călacea and Steluța, and were analyzed 7 varieties of plum
(,Tuleu timpuriu', ,Stanley', ,Gras Ameliorat', ,Anna Spath', ,Tuleu gras', ,Vinete Românești', ,Vinete de Italia' and ,Nectarină roșie'). Determinations regarding the influence of thinning have been made for these varieties on: flower pollination $(\%)$, fruit weight $(\mathrm{g})$ and fruit firmness $\left(\mathrm{Kgf} / \mathrm{cm}^{2}\right)$. Chemical thinning was applied to flowers when $80 \%$ were open, with the following products: Ethrel, $0.01 \%$ concentration, Cosavet 80 DF, 5\% concentration, Sulphur $80 \mathrm{WG}$ and Sulfomat 80 PU, 5\% concentration. Fruit weight was measured by using electronic scale and fruit firmness was determined by penetrometer method with laboratory penetrometer setamatic 17200-6 controller. Of each variety were analyzed 100 fruits, and the results were processed by ANOVA test.

Results and Discussion. Regarding fecundation percentage, both factors and also their inte- 
raction have a very important influence, beginning with the variety $(\mathrm{F}=615.821, \mathrm{p}<0.000)$, treatment $(\mathrm{F}=341.006, \mathrm{p}<0.000)$ and variety $\mathrm{x}$ treatment interaction $(F=32.254, p<0.000)$. In Călacea fruit-growing ecosystem, regardless the treatment, ,Tuleu Timpuriu' variety registered the highest percentage of binding / fertilized flowers (28.66\%), followed by ,Stanley' variety (26.33\%), ,Gras Ameliorat' variety (18.23\%) and ,Anna Spath' variety (14.03\%). In Agroindustriala fruitgrowing ecosystem, the highest percentage was obtained by ,Vinete Românești' variety (29.16\%), followed by ,Nectarină Roșie' variety (28.08\%), 'Vinete de Italia' (26.08\%), 'Stanley' (24.78\%) and 'Tuleu Gras' variety (15.6\%). Regardless the variety, in Călacea fruit-growing variety the highest percentage of fertilized flowers was registered in the case of Cosavet $(27.08 \%)$, and Sulfomat $(26.91 \%)$ treatments, and the lowest percentage was registered by the variant with no treatment applied (13.76\%). In Agroindustriala fruit-growing ecosystem, treatments with Cosavet $(31.58 \%)$ and Sulphur $(30.59 \%)$ registered the highest percentages of fertilized flowers, and the lowest percentage was obtained by the variant with no treatments applied (16.13\%). Analyzing fruit firmness, the two factors, together with their interaction have a very signifying influence, begining with the variety $(\mathrm{F}=510.903, \mathrm{p}<0.000)$, variety $\mathrm{x}$ treatment interaction $(\mathrm{F}=110.1302, \mathrm{p}$ $<0.000)$ and treatment $(\mathrm{F}=60.448, \mathrm{p}<0.000)$. It can be observed that in Călacea fruit-growing ecosystem, regardless the treatment, ,Stanley' variety registered the highest fruit firmness (36.95 $\left.\mathrm{kgf} / \mathrm{cm}^{2}\right)$, followed by 'Anna Spath' variety $\left(35.58 \mathrm{kgf} / \mathrm{cm}^{2}\right)$, 'Gras Ameliorat' variety (26.69 $\mathrm{kgf} / \mathrm{cm}^{2}$ ) and 'Tuleu Timpuriu' variety (25.81 kgf/ $\mathrm{cm}^{2}$ ). In Agroindustriala fruit-growing ecosystem, the highest values for fruit firmness were obtained by 'Stanley' (36.55 $\left.\mathrm{kgf} / \mathrm{cm}^{2}\right)$, being followed by 'Vinete de Italia' variety $\left(31.76 \mathrm{kgf} / \mathrm{cm}^{2}\right)$, 'Vinete Românești' (28.39 kgf $/ \mathrm{cm}^{2}$ ) variety, 'Nectarină Roșie' variety (26.05 kgf $/ \mathrm{cm}^{2}$ ) and 'Tuleu Gras' variety $\left(24.97 \mathrm{kgf} / \mathrm{cm}^{2}\right)$. Concerning fruit weight, both the factors and their interaction have a very signifying influence, beginning with the variety ( $\mathrm{F}=432.948, \mathrm{p}<0.000)$, and continuing with the treatment $(\mathrm{F}=108.106, \mathrm{p}<0.000)$ and variety $\mathrm{x}$ treatment interaction $(F=50.179, p<0.000)$. It can be seen that regardless the treatment, in Călacea fruit-growing ecosystem the highest fruit weight (g) was registered by 'Stanley' variety (48.05g), being followed by 'Anna Spath' variety (42.62 g), ,Gras Ameliorat' variety (39.12 g) and ,Tuleu Timpuriu' variety (33.67 g) and in Agroindustriala fruit-growing ecosystem the highest values for fruit weight were obtained by ,Nectarină Roșie' variety (53.41 g), followed by 'Tuleu Gras' variety (34.86 g), ,Stanley' variety (33.27 g), 'Vinete de Italia' variety (32.4 g) and ,Vinete Românești' variety $(17.73 \mathrm{~g})$.

Conclusion. Studying the two fruit-growing ecosystems, climatic differences can be observed in the same production technology. Giving the results, it can be observed that production, an important parameter, depends on the number of fruits on the tree. A higher number of fruits/ tree mean inferior quality, reserves exhaustion and last but not least, a decrease in trees cold resistance.

\section{REFERENCES}

1. Dagar A, Weksler A, Friedman H. and Lurie S (2012). Gibberellic acid (GA3) application at the end of pit ripening: Effect on ripening and storage of two harvests of 'September Snow' peach, Sci. Hortic. 140, 125-130.

2. Webster AD and Spencer JE (2000). Fruit thinning plums and apricots, plant growth regul., 31, 101-112.

3. Wilkie JD, Sedgley M and Olesen T (2008). Regulation of floral initiation in horticultural trees, J. Exp. Bot. 59:12, 3215-3228. 